\title{
Endoscopic treatment of the fistulas after laparoscopic sleeve gastrectomy and Roux-en-Y gastric bypass
}

\section{Tratamento endoscópico das fístulas após gastrectomia vertical e bypass gástrico em Y de Roux}

\author{
Luís Gustavo Santos Périssé1; Paulo Cezar Marques Périssé, eCBC/RJ2; Celso Bernardo Júnior ${ }^{1}$
}

A B S T R A C T

\begin{abstract}
Objective: to evaluate the use of endoscopic self-expandable metallic prostheses in the treatment of fistulas from sleeve gastrectomy and Roux en y gastric bypass. Methods: all patients were treated with fully coated auto-expandable metallic prostheses and were submitted to laparoscopic or CT-guided drainage, except for those with intracavitary drains. After 6-8 weeks the prosthesis was removed and if the fistula was still open a new prostheses were positioned and kept for the same period. Results: the endoscopic treatment was successful in $25(86.21 \%)$ patients. The main complication was the migration of the prosthesis in seven patients. Other complications included prosthesis intolerance, gastrointestinal bleeding and adhesions. The treatment failed in four patients $(13.7 \%)$ one of which died (3.4\%). Conclusion: endoscopic treatment with fully coated self-expandable prosthesis was effective in treating most patients with fistula after sleeve gastrectomy and roux en y gastric bypass.
\end{abstract}

Key words: Fistula. Postoperative Complications. Endoscopy, Gastrointestinal. Prosthesis.

\section{INTRODUCTION}

$\mathrm{O}$ besity is now a major worldwide public health problem. The World Health Organization estimates that one quarter of the world's population has overweight or obesity ${ }^{1}$ 3. Obesity-related diseases such as type 2 diabetes, hypertension, dyslipidemia, myocardial infarction, stroke, sleep disorders, asthma, depression and degenerative diseases are responsible for about 2.5 million deaths a year in the world ${ }^{2}$.

For patients diagnosed with morbid obesity, surgical treatment is considered the best treatment option. Currently, the two most used surgical techniques are the gastric sleeve (GS) and the Roux-en-Y gastric bypass (RYGB), both performed laparoscopically ${ }^{4}$. Major complications associated with these techniques are postoperative fistula and gastrointestinal bleeding $(1.9 \%)^{5-8}$.

Postoperative fistula is a major challenge for the medical staff, since it is difficult to diagnosis and its treatment is complex and multidisciplinary, involving the control of sepsis, multiple organ failure, nutritional deficit and the fistula itself9,10. The proposed therapeutic options range from conservative medical treatment to exploratory laparotomy with primary closure of the fistula and, in cases of abdomi- nal contamination, which are the majority, radiological or laparoscopic drainage $\mathrm{e}^{8,10,11}$.

Endoscopic treatment is an alternative to surgery. Based on the use of self-expandable prosthesis, endoscopic treatment appeared initially to manage malignant fistulas and esophageal spontaneous perforation (Böerhaave syndrome), and subsequently has been proposed for postoperative leaks ${ }^{12-14}$.

The aim of this study was to evaluate the result of using a self-expandable, completely coated, metal prosthesis in patients diagnosed with reducing post-gastric fistula.

\section{METHODS}

In the Serviço de Endoscopia Digestiva of the Hospital Universitário Gaffrée e Guinle, we evaluated the medical records of patients who underwent surgical treatment for obesity between August 2011 and May 2014 who had postoperative fistula. All patients were from private institutions and operations were carried out by different teams.

Fistula diagnosis was made by clinical examination (tachycardia, fever, tachypnea), laboratory

1. Serviço de Endoscopia Digestiva, Hospital Universitário Gaffrée e Guinle, Universidade Federal do Estado do Rio de Janeiro (UNIRIO) - RJ - Brazil; 2. Curso de Pós-Graduação em Endoscopia Digestiva, Pontifícia Universidade Católica do Rio de Janeiro (PUC-Rio) - RJ Brazil. 
tests (increased $C$ reactive protein), computed tomography (identification of intra-abdominal collection) and the intake of methylene blue if the patient still had the abdominal drain.

After the surgical or radiological treatment of the collection, all patients were transferred to the operating room and underwent endoscopic procedure under general anesthesia in the supine position. After the passage of the endoscope and location of the fistula, contrast infusion was made for the fistula study. After this first step, the external marking was made with electrodes placed below the fistula and the fistula topography. In patients undergoing RYGB, the distal marking was located below the gastrojejunostomy. In patients undergoing GS, the distal marking was located below the surgical reinforcement near or just after the pylorus. In all patients, the proximal portion of the prosthesis was positioned in the distal esophagus. After labeling with electrodes, we positioned a Savary-Gilliard guide wire (Wilson Cook Medical Inc., Winston-Salem, NC) under endoscopic view and over which we introduced the $15 \mathrm{~cm}$ self-expandable metal prosthesis (Boston Scientific of Brazil Ltda). With the prosthesis in its final position, we performed contrast infusion to confirm the path obliteration. In the absence of contrast material in the abdominal cavity, the procedure was considered satisfactory, and we then positioned the metal clips securing the proximal part of the prosthesis wall of the esophagus in order to reduce the possibility of migration. If there was prosthesis migration, we reassessed the patient before the end of the treatment and the prosthesis, repositioned, or replaced by a new one.

\section{RESULTS}

We evaluated the records of 29 patients, 23 (79.3\%) undergoing GS and six (20.6\%), RYGB. Initial BMI ranged from 37.11 to 67.2. Eight patients had no risk factors, while 11 had more than one risk factor (Table 1). The mean age was 36.7 years and the average time between diagnosis of the fistula and the positioning of the prosthesis, six days. Twelve patients were male and 17 female, the average treatment time with the prosthesis being 63 days and the average number of endoscopies, three.

Endoscopic treatment closed the fistula in 25 patients $(86.21 \%)$. There was recanalization of the fistula after six months of prosthesis placement in one patient. He underwent a new endoscopic treatment that permanently closed the fistula. The drainage of intra-abdominal abscess was required in 21 patients. In 19 (65.5\%), surgical drainage was performed (laparotomy), in two (6.89\%) CT-guided drainage was performed and seven patients $(24.1 \%)$ had the cavity drain at diagnosis; in two of these patients the gastric banding had already been positioned. In one patient (3.4\%) we observed a discrete amount of gas in the abdominal cavity without collection at CT, requiring no drainage.
In all patients undergoing GS, the fistula was located in the Hiss angle (Figures 1A, 1B and 1C). One patient, beyond this fistula, presented another one, located in the gastric antrum. In patients undergoing RYGB, two had total dehiscence of the gastric pouch suture (Figures $2 \mathrm{~A}$ and $2 \mathrm{~B}$ ), two had fistula in the pouch suture line and two in the pouch anastomosis with the jejunum.

In the six patients undergoing RYGB, the fistula healed after placement of the prosthesis, with an average of 2.5 endoscopies per patient. Three patients required three endoscopies to rescue the prosthesis, which migrated to the jejunum. To such rescue we used the double balloon enteroscope in one patient and the colonoscope in two other patients; in three patients the fistulas were already healed.

For patients undergoing GS, the placement of the prosthesis was effective and healed the fistula in 19, with an average of 2.7 endoscopies per patient. In 11 patients (57.8\%) two endoscopies were necessary. In two patients the fistula remained open on the date of prosthesis removal. New prostheses were positioned that lasted for over six weeks, when then were removed and there was complete healing of the fistula. In two other patients, at the time scheduled for withdrawal the prosthesis was adhered, requiring the placement of new fully coated prosthesis. In both cases, after 15 days, the two prostheses were removed and the fistula found to be closed. In four patients there was subsequent migration of the prosthesis, which led to an increase in treatment time and in the number of procedures. The main complications found were migration, adhesion, bleeding and intolerance (Table 2). In four patients $(13.7 \%)$ endoscopic treatment was not effective, and one of these died after 22 days of treatment.

\section{DISCUSSION}

Postoperative fistulas represent a serious complication of obesity surgical treatments. The increased intraluminal pressure caused by anastomotic stenosis, excessive tension on the suture line, tissue ischemia and hematoma are predisposing factors. In addition, there are preoperative factors that favor the emergence of complications in the postoperative period: BMI e" 40, hypertension, diabetes, infections, sleep apnea, age over 55 years, male gender, previous surgery and smoking ${ }^{15}$. In this study, 21 patients $(72.4 \%)$ had at least one of these factors preoperatively.

The location of the fistula differs according to the technique proposed ${ }^{2}$. In this series all patients undergoing gastric sleeve (GS) had fistulas at the Hiss angle and one of them also had another leak in the gastric antrum. In patients undergoing Roux-en-Y gastric bypass (RYGB), fistulas were located in the gastrojejunostomy and at the suture line of the gastric pouch, location similar to that found by other authors². 
Table 1 - Epidemiological data.

\begin{tabular}{|c|c|c|c|c|c|}
\hline Patients & Gender & Age & BMI & Risk factors & Surgery \\
\hline 1 & M & 27 & 41.02 & $A$ & GB \\
\hline 2 & $M$ & 28 & 45.56 & & GS \\
\hline 3 & M & 37 & 46.31 & A-H-D-B & GS \\
\hline 4 & $\mathrm{~F}$ & 35 & 40.22 & $\mathrm{H}-\mathrm{C}$ & GS \\
\hline 5 & $\mathrm{~F}$ & 67 & 37.83 & $H-D-B$ & GS \\
\hline 6 & $\mathrm{~F}$ & 34 & 37.26 & $\mathrm{H}-\mathrm{C}$ & GS \\
\hline 7 & $M$ & 39 & 44.01 & & GS \\
\hline 8 & $\mathrm{~F}$ & 55 & 37.58 & & GS \\
\hline 9 & $M$ & 22 & 50 & $\mathrm{~A}-\mathrm{H}$ & GB \\
\hline 10 & $M$ & 35 & 46.61 & $\mathrm{~A}-\mathrm{H}$ & GB \\
\hline 11 & $M$ & 51 & 40.48 & $A-C$ & GS \\
\hline 12 & $M$ & 40 & 46.08 & & GB \\
\hline 13 & $\mathrm{~F}$ & 18 & 45 & $\mathrm{H}$ & GS \\
\hline 14 & $\mathrm{~F}$ & 36 & 48.56 & & GS \\
\hline 15 & $\mathrm{~F}$ & 42 & 51.69 & C & GB \\
\hline 16 & $\mathrm{~F}$ & 34 & 67.2 & $\mathrm{H}$ & GB \\
\hline 17 & M & 24 & 40.04 & $\mathrm{~A}-\mathrm{H}$ & GS \\
\hline 18 & $\mathrm{~F}$ & 40 & 40.65 & $C$ & GS \\
\hline 19 & $\mathrm{~F}$ & 33 & 37.11 & $\mathrm{H}$ & GS \\
\hline 20 & M & 25 & 40.07 & $\mathrm{H}$ & GS \\
\hline 21 & $\mathrm{~F}$ & 18 & 51.42 & & GS \\
\hline 22 & $\mathrm{~F}$ & 39 & 37.59 & $A$ & GS \\
\hline 23 & $\mathrm{~F}$ & 53 & 44.66 & $A-H-D$ & GS \\
\hline 24 & $M$ & 38 & 47.84 & $\mathrm{~A}-\mathrm{H}$ & GS \\
\hline 25 & $\mathrm{~F}$ & 36 & 44.41 & $A-C$ & GS \\
\hline 26 & $\mathrm{~F}$ & 54 & 39,43 & A-H-D-C & GS \\
\hline 27 & M & 38 & 38.89 & $A$ & GS \\
\hline 28 & $\mathrm{~F}$ & 31 & 36 & & GS \\
\hline 29 & $\mathrm{~F}$ & 38 & 43.92 & & GS \\
\hline
\end{tabular}

Source: Digestive Endoscopy Service of the Gaffrée e Guinle University Hospital.

Legends: A - Obstructive sleep apnea; H - Systemic arterial hypertension; D - Diabetes; C - Previous laparotomy; B - gastric band; GB - gastric bypass; GS - sleeve gastrectomy.
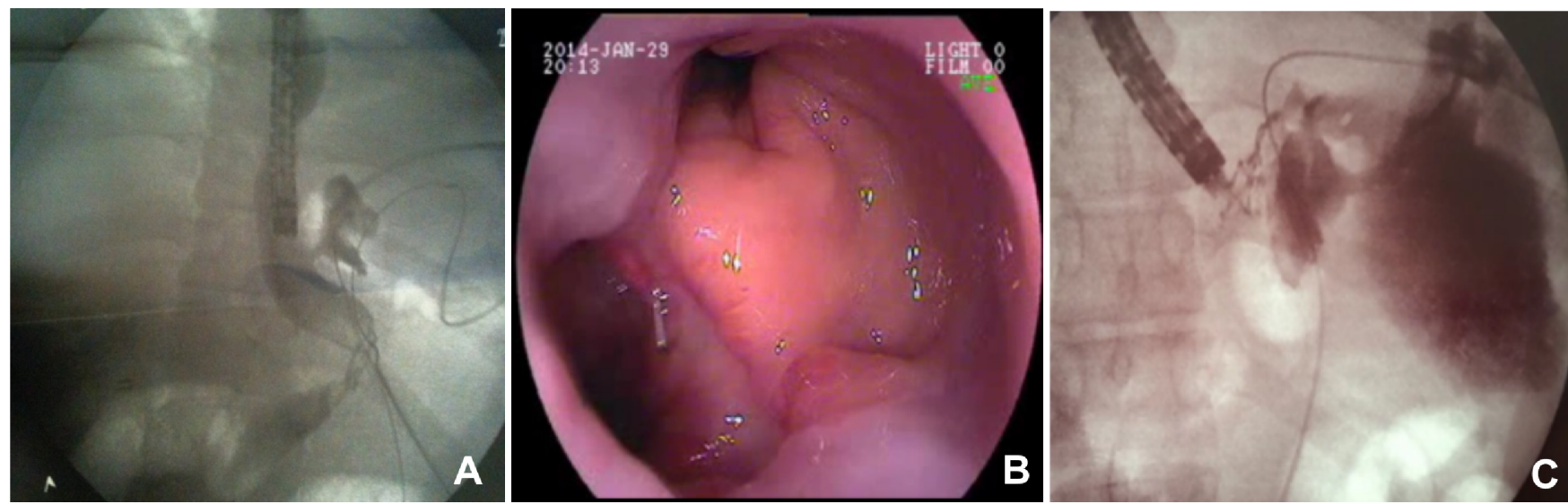

Figure 1 - A) simple Hiss angle fistula; B) endoscopic appearance of a complex fistula at the Hiss angle; C) X ray image of the complex fistula at the Hiss angle with abdominal abscess. 


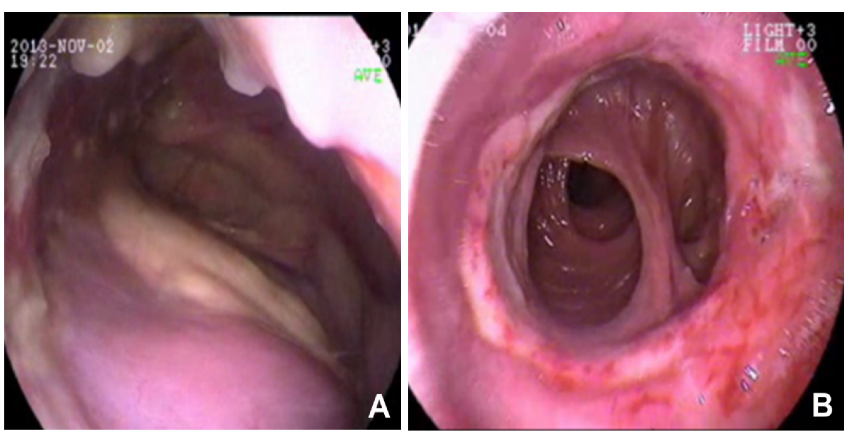

Figure 2 - A) total dehiscence of gastric pouch with visualization of the liver; B) gastric pouch after treatment.

The male gender is an independent risk factor for fistula ${ }^{6}$. This can be explained by the higher central fat in relation to peripheral fat, leading to increased amount of intra-abdominal and mesenteric fat. In our study, $41.3 \%$ were men, $56.7 \%$ were women. This apparently contradictory results can be explained by the higher number of women undergoing surgical treatment.

Postoperative fistulas usually occur between the second and 12th day after the operation and are difficult to diagnose. The main symptom is tachycardia (72-92\%), followed by nausea and vomiting (81\%), fever (62\%) and leukocytosis $(48 \%)^{1,16,17}$. Computed tomography (CT) is the best imaging method for the diagnosis and assists the conduct as to whether or not to drain the abdomen, although its validity for the fistula diagnosis in patients with BMI e" 50 is questioned due to size of waist circumference ${ }^{15}$. In patients in whom the cavity drain remains positioned, methylene blue administered orally can be very useful for confirming the fistula. In 23 patients (79\%) the diagnosis was made by the tenth day, in three $(10.3 \%)$, until the 15 th day, and in th remaining three (10.3\%), after 30 days. In 21 patients the diagnosis was made by CT with contrast and in eight patients, with methylene blue. Once the fistula diagnosis is confirmed, operative treatment has been proposed by many centers of bariatric surgery in the world ${ }^{18}$, but the technical difficulties associated with the high incidence of fistula recurrence, possibly caused by the intense inflammation in its surroundings, led this option to be underutilized. In order to reduce the complications inherent to operative rapprochement, it has been proposed that the operation be limited to drainage of possible abdominal abscesses and the fistula approach be made preferably endoscopically9,15,19 . In our series, two patients submitted to RYGB underwent operative fistula rapprochement without success, increasing time between diagnosis and endoscopic treatment. In all other patients previously addressed by surgical teams the approach was the drainage of intra-abdominal collection.

The endoscopic technique is based on the use of a completely coated prosthesis associated, when required, the use of "Surgisis plugs" (Wilson Cook Medical, Inc., Winston-Salem, NC). After the positioning, the prosthesis leads to the formation of a mechanical barrier between the gastrointestinal tract and the fistula, allowing high protein oral nutritional support while healing occurs ${ }^{8}$. The use of oral feeding avoids complications related to parenteral nutrition. Moreover, premature discharge reduces the risk of infection ${ }^{1,20}$. After positioning, the prostheses are generally well accepted by patients. Usually found complications are migration, transient chest pain during expansion, nausea, gastrointestinal bleeding, adhesion and intolerance ${ }^{4,15}$. In this study there was prosthesis migration in three patients submitted to RYGB and in four submitted to GS. This complication is the biggest problem of the endoscopic treatment and is caused by the prostheses design, originally meant to be used in the esophagus ${ }^{11}$. One of the proposed ways to prevent prosthesis migration is the use of metal staples in the proximal part of the prosthesis in order to attach it to the esophagus ${ }^{20,21}$. We adopted this conduct for all patients in this series.

The literature describes one severe gastrointestinal bleeding case as a result of an aortic-esophagic fistula caused by the prosthesis ${ }^{22}$. Only one of our patients had bulky gastrointestinal bleeding, starting 24 hours before the expected prosthesis removal time. In this case, an approach to suppress the bleeding was not necessary, and during the removal of the prosthesis we observed a large stomach ulcer, probably caused by contact of the prosthesis with the gastric mucosa.

Although we have used only fully coated prostheses, in two patients there was silicone rupture, resulting in tissue growth and prosthesis adhesion. In these two patients we placed new fully coated prostheses of equal sizes inside the attached prostheses and patients were discharged. After 15 days, during a novel hospital admission, the two prostheses were withdrawn. This approach is used

Table 2 - Complications of endoscopic treatment.

\begin{tabular}{|c|c|c|}
\hline Complications & $N(\%)$ & Treatment \\
\hline Migration & $7 \quad(24.3)$ & 3 removed * \\
\hline Adherence & $2 \quad(6.8)$ & 4 replacements - prosthesis under prosthesis \\
\hline Intolerance & $1 \quad(3.4)$ & removed \\
\hline Bleeding & $1 \quad(3.4)$ & conservative treatment \\
\hline
\end{tabular}

Source: Digestive Endoscopy Service of the Gaffrée e Guinle University Hospital.

* Fistulas already healed at the time of migration. 
in the removal of partially coated prostheses in which there is cell growth in the proximal and distal segments ${ }^{21,23}$. There is no consensus in the literature as to the time for prosthesis removal. Published papers report a period between four and eight weeks ${ }^{20,24}$. In our series, the average time of prosthesis stay was 9.4 weeks.

We removed the prostheses from four patients. One patient complained of severe heartburn and chest pain and requested the removal of the prosthesis before the time deemed necessary for fistula closure. In this patient there was a significant reduction in the size of the fistula and abdominal collection during the period in which the prosthesis remained positioned. After its withdrawal, we positioned "Surgisis plugs" (Wilson Cook Medical Inc., Winston-Salem, NC), with total occlusion of the path ten days after. In another patient there was a reduction of the fistula caliber after the proposed period and the patient was discharged on enteral feeding until the complete obliteration of the path. In the third patient there were numerous treatment attempts, endoscopic and clinical, all unsuccessful, and at the end of seven months the patient was referred for total gastrectomy. In this series, the one patient (3.4\%) evolving to death presented one fistula located in the Hiss angle and another in the gastric antrum.
Antrum fistulas are difficult to manage and often do not respond satisfactorily to treatment with the prosthesis; it is believed that antral postoperative anatomical changes hamper the obliteration of the fistula.

An important aspect to be considered in this work is that all patients were from different teams from various private institutions and that for the first patients there was no uniform acceptance of endoscopic fistulas treatment from all teams. Thus, there was a significant variation in the timing of indication of endoscopic treatment. This delay may have led to the formation of chronic fistula, reducing prosthesis effectiveness ${ }^{18,20}$. Since there are no randomized studies on the treatment of postbariatric fistulas with the use of prostheses, the level of evidence is not strong. However, our work shows that treatment with prosthesis is safe and presents significant healing results. Other endoscopic techniques should always be complementary and one should not initially indicate surgical treatment for fistulas, which should be limited to collection drainage $9,15,19$.

In conclusion, the endoscopic approach with the use of completely coated, self-expandable prosthesis was effective in treating most patients with fistula after gastric sleeve and Roux-en-Y gastric bypass.

\title{
R E S U M O
}

\begin{abstract}
Objetivo: avaliar a utilização das próteses metálicas autoexpansivas no tratamento das fístulas pós-gastroplastia redutora. Métodos: todos os pacientes foram tratados com próteses metálicas autoexpansivas totalmente recobertas e, exceto aqueles que apresentavam drenos intracavitários, foram submetidos à drenagem por via laparoscópica ou guiada por TC. Após seis a oito semanas, a prótese era retirada e, caso a fístula ainda estivesse aberta, novas próteses eram posicionadas e permaneciam por igual período. Resultado: o tratamento endoscópico obteve sucesso em 25 (86,21\%) pacientes. A principal complicação foi a migração da prótese, ocorrida em sete pacientes. Outras complicações foram intolerância à prótese, hemorragia digestiva e aderência. 0 tratamento não teve êxito em quatro pacientes $(13,7 \%)$, sendo que um $(3,4 \%)$ faleceu. Conclusão: a abordagem endoscópica com a utilização de prótese autoexpansiva, totalmente recoberta, foi eficaz para tratar a maioria dos pacientes com fístula pósgastroplastia redutora.
\end{abstract}

Descritores: Fístula. Complicações Pós-Operatórias. Procedimentos Cirúrgicos Endoscópicos Gastrointestinais. Implante de Prótese

\section{REFERENCES}

1. Kumar N, Thompson CC. Endoscopic management of complications after gastrointestinal weight loss surgery. Clin Gastroenterol Hepatol. 2013;11(4):343-53.

2. Yurcisin BM, Gaddor MM, DeMaria EJ. Obesity and bariatric surgery. Clin Chest Med. 2009;30(3):539-53.

3. Buchwald $H$, Avidor $Y$, Braunwald $E$, Jensen MD, Pories W, Fahrbach $K$, et al. Bariatric surgery: a systematic review and meta-analysis. JAMA. 2004:292(14):1724-37. Erratum in: JAMA 2005;293(14):1728.

4. Jurowich C, Thalheimer A, Seyfried F, Fein M, Bander G, Germer $C T$, et al. Gastric leakage after sleeve gastrectomy - clinical presentation and therapeutic options. Langenbecks Arch Surg. 2011;396(7):981-7.

5. El Mourad H, Himpens J, Verhofstadt J. Stent treatment for fístula after obesity surgery: results in 47 consecutive patients. Surg Endosc. 2013;27(3):808-16.
6. Simon F, Sicilliano I, Gillet A, Castel B, Coffin B, Msika S. Gastric leak after laparoscopic sleeve gastrectomy: early covered selfexpandable stent reduces healing time. Obes Surg. 2013;23(5):68792.

7. Babor R, Talbot M, Tyndal A. Treatment of upper gastrointestinal leaks with a removable, covered, self-expanding metallic stent. Surg Laparosc Endosc Percutan Tech. 2009;19(1):e1-4

8. de Aretxabala X, Leon J, Wiedmaier G, Turu I, Ovalle C, Maluenda F. Gastric leak after sleeve gastrectomy: analysis of its management Obes Surg. 2011;21(8):1232-7.

9. Puli SR, Spofford IS, Thompson CC. Use of self-expansible stents in the treatment of bariatric surgery leaks: a sistematic review and meta-analysis. Gastrointest Endosc. 2012;75(2):287-93.

10. de Moura EG, Galvão-Neto MP, Ramos AC, de Moura ET, Glvão TD, de Moura DT, et al. Extreme bariatric endoscopy: stenting to reconnect the pouch to the gastrojejunostomy after a Roux-en-Y gastric bypass. Surg Endosc. 2012;26(5):1481-4. 
11. Eubanks S, Edwards CA, Fearing NM, Ramaswamy A, de la Torre RA, Thaler KJ, et al. Use of endoscopic stents to treat anastomotic complications after bariatric surgery. J Am Coll Surg. 2008;206(5):935-8; discussion 938-9.

12. D'Cunha J, Rueth NM, Groth SS, Maddaus MA, Andrade RS. Esophageal stents for anastomotic leaks and perforations. J Thorac Cardiovasc Surg. 2011;142(1):39-46.e1.

13. Rajan PS, Bansal S, Balaji NS, Rajapandian S, Parthasarathi R, Senthilnathan $P$, et al. Role of endoscopic stents and selective minimal access drainage in oesophageal leaks: feasibility and outcome. Surg Endosc. 2014;28(8):2368-73.

14. Wie W, Ramaswamy A, de la Torre R, Miedema BW. Partially covered esophageal stents cause bowel injury when used to treat complications of bariatric surgery. Surg Endosc. 2013;27(1):5660 .

15. Márquez MF, Ayza MF, Lozano RB, Morales Mdel M, Díez JM, Poujoulet RB. Gastric leak after laparoscopic sleeve gastrectomy. Obes Surg. 2010;20(9):1306-11.

16. BhayaniNH, Swanström LL. Endoscopic therapies for leaks and fístulas after bariatric surgery. Surg Innov. 2014;21(1):90-7.

17. Ballesta C, Berindoague R, Cabrera M, Palau M, Gonzalez M. Management of anastomotic leaks after laparoscopic Roux-en-Y gastric bypass. Obes Surg. 2008;18(6):623-30.

18. Sakran N, Goitein D, Raziel A, Keidar A, Beglaibter N, Grinbaum R, et al. Gastric leaks after sleeve gastrectomy: a multicenter experience with 2,834 patients. Surg Endosc. 2013;27(1):240-5.

19. Donatelli G, Dhumane P, Perretta S, Dallemagne B, Vix M, Mutter $D$, et al. Endoscopic placement of fully covered self expanding metal stents for management of post-operative foregut leaks. J Minim Access Surg. 2012;8(4):118-24.
20. Nguyen NT, Nguyen XM, Dholakia C. The use of endoscopic stent in management of leaks after sleeve gastrectomy. Obes Surg. 2010;20(9):1289-92.

21. Aurora AR, Khaitan L, Saber AA. Sleeve gastrectomy and the risk of leak: a systematic analysis of 4,888 patients. Surg Endosc. 2012;26(6):1509-15.

22. Eisendrath $P$, Cremer $M$, Himpens J, Cadière GB, Le Moine $O$, Devière J. Endotherapy including temporary stenting of fístulas of the upper gastrointestinal tract after laparoscopic bariatric surgery. Endoscopy. 2007;39(7):625-30.

23. van Boeckel PG, Dua KS, Weusten BL, Schmits RJ, Surapaneni $N$, Timmer R, et al. Fully covered self-expansible metal stent (SEMS), partially covered SEMS and self-expansible plastic stents for the treatment of benign esophageal ruptures and anastomotic leaks. BMC Gastroenterol. 2012;12:19.

24. Almadi MA, Bamihriz F, Aljebreen AM. Fatal aortoesophageal fístula bleeding after stenting for a leak post sleeve gastrectomy. World J Gastrointest Surg. 2013;5(12):337-40.

Received on 20/07/2014

Accepted for publication 10/09/2014

Conflict of interest: none.

Source of funding: none.

Adress for correspondence:

Luís Gustavo Santos Périssé

E-mail: luisperisse@yahoo.com.br 